\title{
Reduce the Harmful Effect of High Temperature to Improve the Productivity of Tomato under Conditions of Newly Reclaimed Land
}

\author{
A.G. Zakher * and M.A.A. Abdrabbo ${ }^{* *}$ \\ ${ }^{*}$ Vegetables Research Department, Horticulture Research \\ Institute and ** Central Laboratory for Agricultural Climate \\ (CLAC), Agricultural Research Centre, Cairo, Egypt.
}

\begin{abstract}
7 HE GROWTH and productivity of tomato (Solanum lycopersicon L. Alissa F1 hybrid) is affected by environmental factors and agronomical techniques. There were seven treatments used to minimize the injury of high temperature during the summer season, i.e: two shade net treatments (black or green), two spray treatments i.e. Purshade or sea algae (Robin Pro), two intercropping treatments (maize or sunflower) in comparison with the control (without any treatment). Tomato was cultivated during two studies season in the 'Amoun Agricultural Society, Eltal El Kabier, Cairo- Ismailia Desert Road, Ismailia Governorate, Egypt during late summer seasons of 2012 and 2013. This study investigated the effect of different techniques of protected cultivation against unfavorable condition of high temperature on the growth and production of tomato in terms of air temperature, relative humidity and light intensity. Plant growth was evaluated over the two seasons. All physical protected cultivation treatments (cover net or intercropping) decreased light intensity, maximum temperatures and increased relative humidity compared with open field conditions without protection treatment. The black cover net was the most effective method to decrease the air temperature by from 2 to $3^{\circ} \mathrm{C}$ followed by green net (about $2^{\circ} \mathrm{C}$ ), the intercropping was less effective to decrease temperature $\left(1^{\circ} \mathrm{C}\right)$. Green and black net produced the highest significant plant height, number of branches, fresh and dry weight per plant. Moreover, green and black net shortest period from transplanting to flowering comparing to the other treatments, i.e. intercropping with maize and sunflower as well as the control treatments. The earliest and the highest tomato total yield were obtained by using the green net cover followed by black net cover while the latest and the lowest total yield was obtained under control treatment (un shaded). Moreover, the higher fruit length, fruit diameter, fruit wall thickness and number of locules associated with the use of the green net in comparison with other protected cultivation treatments as well as the control during the two seasons. There were no significant among the treatments in fruit color and juice acidity during the two seasons.
\end{abstract}

Keywords: Color net, Solar Radiation, Light intensity, Relative humidity, Fruit quality.

Tomato (Solanum lycopersicon Mill.) is one of the most important vegetable crops in Egypt, and other world countries for fresh consumption, industry processing and exportation. Increasing the production and the quality of tomato fruits is very 
important objective to meet the higher human population demand. Furthermore, it is well known that, a serious reduction in tomato production, in Egypt, was occurred as a result of unfavorable high temperature prevailing during the period of late summer season (May, June, July and August). The total area devoted to tomato crop during 2010 was 262054 feddans in summer plantations/ this area produced 4121066 tons with an average yield of 15.726 ton/Fedden*

However, heat stress severally affects photosynthesis, carbohydrates through depletion in respiration, protein breakdown and de-nitration, nutritional and hormonal imbalances, enzyme inactivation, disturbances in membrane structure and restriction of stomatal function (Dubey, 1997 and Karim et al., 1999).

Gaseous emissions due to human activities are substantially adding to the existing concentrations of greenhouse gases, particularly $\mathrm{CO}_{2}$, methane, and nitrous oxides. Different global circulation models predict that greenhouse gases will gradually increase world's average ambient temperature. According to a report of the Intergovernmental Panel on Climatic Change (IPCC, 2006), global mean temperature will rise $0.3{ }^{\circ} \mathrm{Cper}$ decade (Jones et al., 1999) reaching to approximately 1 and $3 \circ \mathrm{C}$ above the present value by years 2025 and 2100 , respectively, leading to global warming.

Abdrabbo et al. (2013) studied planting and the growth of potato under different net color as well as in open field, they reported that the highest temperature was recorded in the open field treatment followed by white net, while the lowest temperature was gained by black net. Maximum temperatures tended to be lower under the blue and black net by $3^{\circ} \mathrm{C}$ in comparison with open field, while average relative humidity increased with the use of all net color by 4 $8 \%$ compared to open field (Wilson and Rajapakse, 2001).

Due to the high microclimatic requirements of the culture, the installations for this kind of cultivation have a technically good level, varying the number of covering according to the local solar radiation (Iglesias and Alegre, 2006), It is preferred to cultivate this species in regions where mountains predominate, but as the market demand increases, the culture has been installed in places where the climate, at first, is inhospitable. As a consequence to this fact, a higher investment in the microclimate is required. Among the problems that affect this cultivation, the low temperatures during the winter and the excess of temperature and solar radiation in summer (Abou-Hadid and El-Beltagy, 1992).

Concerning to use shading with black net it is led to increasing plant height, chlorophylls, average fruit weight, and total yield. The colored net is an emerging approach, which introduces additional benefits, on top of the various protective functions of nettings. These nets are unique in that they both spectrally-modify, as well as scatter the transmitted light (Wilson and Rajapakse, 2001). The photoselective nets include "colored nets" (e.g. Red, Yellow, Green, Blue net products) as well as color nets (e.g. Pearl, White and Grey) absorbing spectral bands shorter, or longer than the visible range. The spectral manipulation is

Egypt. J. Hort. Vol. 41, No.2 (2014) 
aimed at specifically promoting physiological responses, while light scattering improves light penetration into the inner canopy (Rajapakse and Shahak, 2007).

It was found that, compounds containing calcium carbonate such as Purshade that acts as a superior reflective particle barrier to the harmful effects of solar radiation and water stress. Treating late in maturity season grapevines with plant protect ants during summer periods (warm periods) substantially assist in the reduction of sun damage. Under such high sun intensity and temperature above $90^{\circ} \mathrm{F}$ a great damage on all plant parts especially clusters was happene (Karim et al., 1999). These compounds have been shown to increase marketable yield up to $30 \%$ by reducing collage and promoting the production of higher yields. And reduce sun damage (sunburn) by more than $40 \%$ as well as improve fruit quality with larger fruits and/ or better coloring. Reduce all plant stresses by $20-60 \%$ and in turn improve the plants use of available resources. It reflects $90-98 \%$ of harmful ultraviolet (UV) and infrared (IR) radiation without blocking photosynthetic light. Moreover, it keeps plants 7 degrees $\left({ }^{\circ} \mathrm{F}\right)$ cooler by reflecting heat. This reduces stress on the plants and enables basic physiological processes to continue in high temperature when they would normally shut down. The previous benefits of anti sunburn compounds were cited by (Adams et al., 2001).

Concerning of using seaweed extract which is rich in macro and micro elements, important plant hormones like Auxins, Gibberellins and Cytokinin that induce cell division, increase cell enlargement, lead to the balance of physiological and biological processes, increase photosynthesis processes and improve growth characters (Jensen, 2004). Kowalski et al. (1999) describe the significant positive effects of seaweed extract on plant growth and yield of potato plant.

In addition Abdel-Aziz and Zakher (2010) demonstrated that foliar spraywith Robin at $1 \mathrm{~cm}^{3} / \mathrm{L}$ produced significant increases in plant height, number of leaves as well as fresh and dry weights of pea plants.

The aim of this study is to investigate the effect of different plant techniques of protected tomato cultivation i.e. grown under black and green net, intercropping using maize and sunflower with tomato plants, spray with Purshade and Robin (sea algae) as well as open field conditions without using any protection treatment on the growth and production of tomato.

\section{Materials and Methods}

Two field experiments were carried out at Amoun Agricultural Society, El Tal El Kabier (76 km from Cairo), Cairo-Ismailia desert road, Egypt, Ismailia Governorate during the two successive late summer seasons, of 2012 and 2013. Seeds of tomato i.e. Alissa $\mathrm{F}_{1}$ hybrid (produced by Nunhems seeds co. Netherlands) were sown in the nursery on $15^{\text {th }}$ and $20^{\text {th }}$ of April, in 2012 and 2013 , respectively and seedlings were transplanted on $20^{\text {th }}$ and $25^{\text {th }}$ of May in 2012and 2013, respectively. 
The experiment included 7 treatments as follows:

- Shading with black net (60\% shade) under tunnel (length $15 \mathrm{~m}$, width, $1.25 \mathrm{~m}$, height $0.70 \mathrm{~m}$ ).

- $\quad$ Shading with green net ( $30 \%$ shade) under tunnel (length $15 \mathrm{~m}$, width, 1.25 $\mathrm{m}$, height $0.70 \mathrm{~m}$ ).

- Intercropping with maize (Zea mays L.) individual 311maize hybrid (Maka seeds co).

- Intercropping with local sunflower (Helinthus annuus).

- Foliar spray with $8 \mathrm{~cm}^{3}$ Purshade/ L (for reflection of solar radiation).

- Foliar spray with $1 \mathrm{~cm}^{3}$ Robin/L (algae treatment).

- Control (Spraying with tap water).

Seeds of maize and sunflower were sown in the same day of tomato transplanting on the south side of each row alternating with tomato rows at $50 \mathrm{~cm}$ space between seeds, maize and sunflower were thinned to one plant per stand 10 days after planting.

Purshade: a plant protector against solar stress contains $62.5 \%$ calcium carbonate and $37.5 \%$ inert ingredients by weight in organic forms.

Robin Pro Natural: Sea Algae Natural Supplement, Contain multiple macro and micro elements, as well as carbohydrates, minerals, amino acids, vitamins and some substances like auxin on its effect deriving from sea algae (Ascophyllum nodosum).

Spraying treatments: four spraying per season starting at the beginning of flowering stage and repeated every 10 days, the spraying treatments were carried out at early morning.

Drip irrigation was used for irrigate the plants with equal amount of water. The farm soil type was sandy soil. Table 1 shows the mechanical and chemical analyses of experimental soil. Fertigation system was used according to fertilizer recommended program under sandy soil.

TABLE 1. The physical and chemical and analysis of the experimental soil before cultivation.

\begin{tabular}{|c|c|c|c|c|c|}
\hline \multicolumn{6}{|c|}{ Physical properties } \\
\hline \multicolumn{2}{|c|}{ Sand \% } & \multirow{3}{*}{$\begin{array}{l}\text { Clay \% } \\
6.08 \\
\text { Chemi }\end{array}$} & \multicolumn{2}{|c|}{ Silt \% } & Texture \\
\hline \multicolumn{2}{|c|}{88.92} & & \multicolumn{2}{|c|}{5.00} & Sandy \\
\hline \multicolumn{5}{|c|}{ Chemical properties } & \\
\hline $\mathrm{Ca}$ & $\mathrm{Mg}$ & $\mathrm{Na}$ & K & $\mathrm{HCO}_{3}$ & $\mathrm{Cl}$ \\
\hline \multicolumn{6}{|c|}{ meq/l } \\
\hline 1.0 & 0.4 & 0.76 & 0.31 & 1.01 & 0.51 \\
\hline
\end{tabular}

Egypt. J. Hort. Vol. 41, No.2 (2014) 
The following data were recorded during the two growing seasons Environmental Measured

Day light intensity, maximum temperature and humidity were measured under different treatments every day by using digital climatic sensors.

Relative humidity and air temperature: Digital thermo-hygrograph was used to measure temperature and relative humidity (model, TFA Dostman/Wertheim Kat. Nr. 5002), the Digital thermo-hygrograph was allocated over polystyrene trays in the middle of each treatment above the level of tomato plants canopy, the maximum air temperature was recorded at 13:00, the average relative humidity was calculated by the average of maximum and minimum relative humidity everyday, the average weekly maximum temperature and humidity has been calculated using the daily climatic data.

Light intensity: Light intensity was measured in each treatment daily above the tomato plants canopy at mid-day (13:00) by portable Lux-meter (Model FMC- 10M). The average weekly light intensity was calculated from the measured data.

\section{Flowering date}

Number of days from transplanting till $25-50 \%$ flower anthesis per plot was calculated as index of flowering date.

\section{Vegetative growth}

After 65 days from transplanting (at the beginning of fruiting stage), plant height $(\mathrm{cm})$, number of branches, number of leaves, fresh weight $(\mathrm{g})$, dry weight (g) were determined in 3 plants from each plot then the average per plant was calculated. In the same time, the leaves number 4, 5 from the top of the plants were collected and total chlorophyll was determined according to Meter SPAD50I as SPAD unites (Monje and Bugbee,1992).

\section{Flowering characteristics and Yield}

Flowering characteristics were measured by the means of cluster number 3 and 4 on the main stem to determine:

- Clusters number / plant were counted at flowering stage.

- Fruit setting percentage was calculated according to the formula:

$$
\text { No. of setted fruits /cluster }
$$

No. of total flowers / cluster

$$
\text { X } 100
$$

- Early yield and total yield (ton/fed.), and average fruit weight of tomato fruits (g): were calculated as the following: Early yield of tomato fruits (expressed as weight of the first three pickings), the total yield as the weight of fruits of all pickings as kg/ plot, then were summated and calculated as ton/ fed. And average fruit fresh weight $(\mathrm{g})$ was determined theoretically by dividing total fruit weight on the total fruit number. 
Fruit quality

The physical and chemical characteristics of tomato fruits

- A random sample of five fruits per plot was used for measuring fruit length, diameter, flesh thickness (by using a caliper) and number of locules. The measurements were recorded at the same stage from the harvesting in midseason and the averages were calculated. Fruit firmness was measured using a needle type pocked penetro-meter.

- The color characteristics of fruits was determined by a Minolta Chroma Meter, model CR-200.Calibration was done by a white plate before use Color changes were quantified in the $\mathrm{L}=$ lightness, ranging from $0=$ black to $100=$ white , $\mathrm{C}=$ Chroma represents color saturation which varies from dull (low value) to vivid color (high value) and $\mathrm{h}=$ hug angle (McGuire, 1992).

- The percentage of total soluble solids (TSS) in fruit juice was determined by a hand refractor meter according to the methods mentioned in the (A.O.A.C.1990)

- The acidity of fruits juice was determined using a $\mathrm{pH}$ meter.

Statistical design and analysis

The experimental design was complete randomize blocks with three replicates, each experimental plot consisted of $15 \mathrm{~m}$ long and $1.25 \mathrm{~m}$ width with spacing of $40 \mathrm{~cm}$ between plants. Data obtained were analyzed according to Duncan's multiple range tests at 5\% (Waller and Duncan, 1969), which used for the comparisons among the various tested genotypes.

\section{Climatic data}

\section{Results and discussions}

Average maximum air temperatures for the different treatments showed that the use of nets exerted a limited influence on temperature (Fig. 1, 2 and 3). Maximum air temperature tended to be lower under the black and green nets $\left(2-3^{\circ} \mathrm{C}\right)$, due to the interception of radiation which is greater than the gain of temperature caused by the use of nets due to their role in the interception of air circulation or "greenhouse effect". The temperature under shading with maize or sunflower were the same like open field in the first three weeks, after that, the maize and sunflower plants become vigor in its growth and protected the tomato plants. The average maximum air temperature, relative humidity and light intensity for plants grown under maize and sunflower was almost the same in the first three weeks after transplanting, then the maize and sunflower start to grow up and changed the microclimate around tomato plants reducing maximum air temperature by about $1-2{ }^{\circ} \mathrm{C}$, reduce light intensity by about 200-400 foot candle and increase relative humidity by $2-4 \%$. Finally, the climatic measurements were the same during all the season for the open field (without treatment), Purshade as well as Robein algae treatments. There was about one temperature degree less than open field under maize and sunflower. Similar results were reported by Medany et al. (2009), Al-Helal \& Abdel-Ghany (2010) and Abdrabbo et al. (2013), indicating that the influence of nets upon maximum temperatures. Elad et al. (2007) found a moderate decrease in maximum temperatures associated with the use of shade nets, Stamps (2008) reported a moderate decrease

Egypt. J. Hort. Vol. 41, No.2 (2014) 
$\left(<2^{\circ} \mathrm{C}\right)$. Moreover, using net cover led to decrease maximum air temperature in comparison with open field, the lowest maximum temperature was gained by black net. Maximum temperatures tended to be lower under the blue and black net by $3^{\circ} \mathrm{C}$ in comparison with open field, while Average relative humidity increased by the use of all net color by 4-8\% compared to open field (Retamales et al., 2008 and Abdrabbo et al., 2013). Campen and Bot (2003) explained the ventilation phenomenon. The pressure difference over the openings was one of the driving forces for ventilation, which could be either due to the wind outside the greenhouse or due to the temperature difference over the openings. At lower wind speed, which was true under present case, mainly the buoyancy effect contributes in ventilation (Wilson and Rajapakse, 2001).

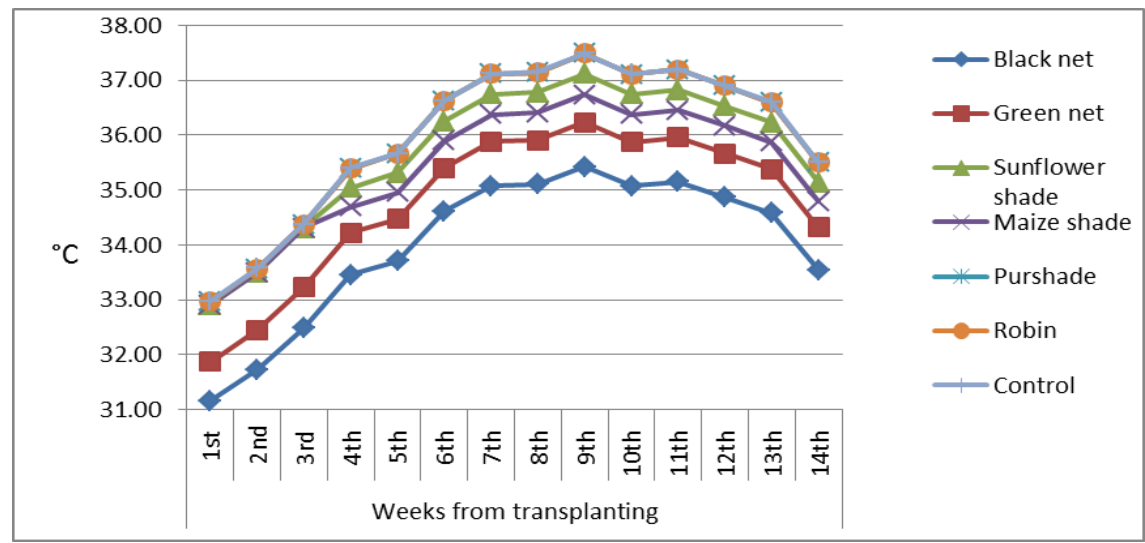

Fig. 1. Weekly average maximum air temperature $\left({ }^{\circ} \mathrm{C}\right)$ under different treatments during the two studied seasons of $2012-2013$.

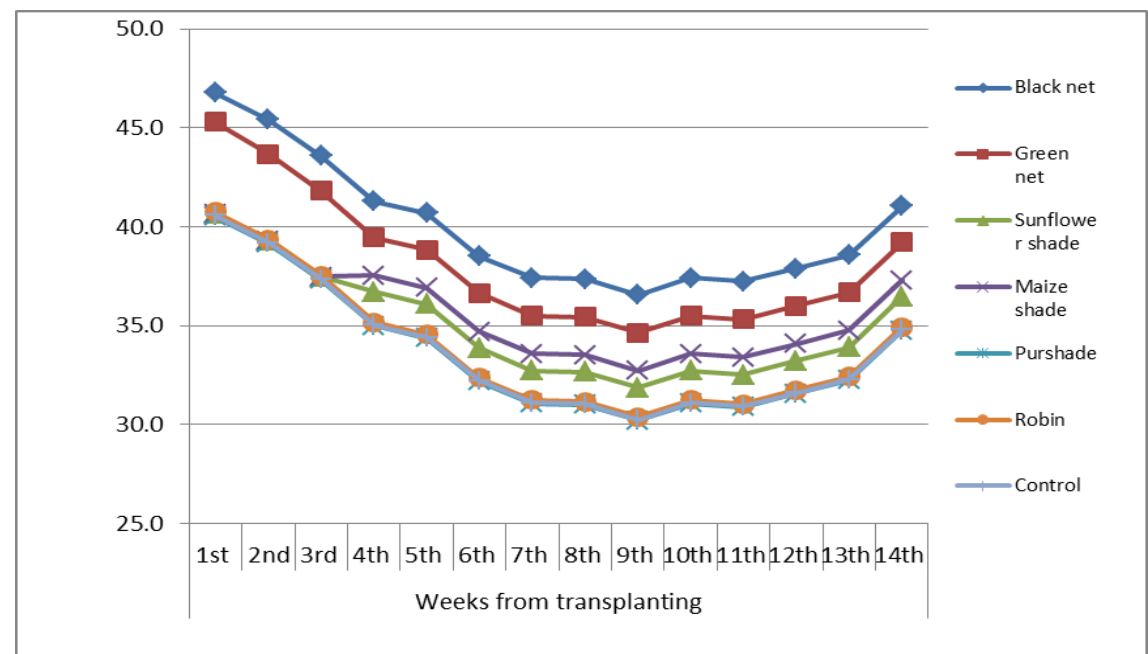

Fig. 2. Weekly average relative humidity (\%) under different treatments during the two studied seasons of $2012-2013$. 


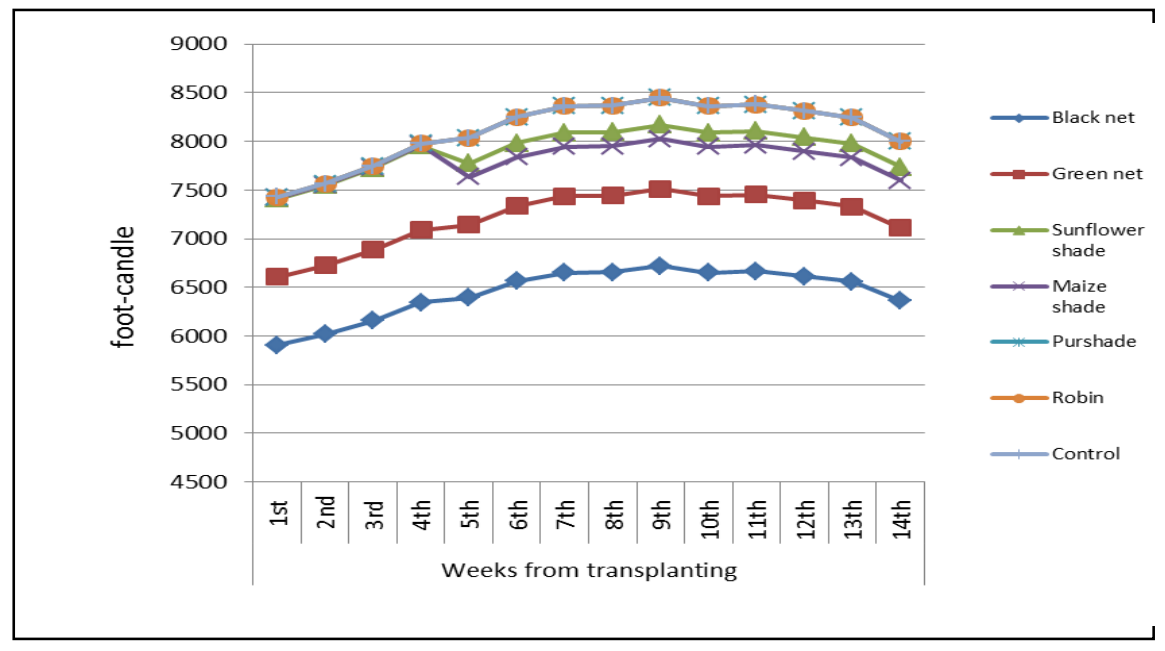

Fig. 3. Weekly average light intensity (foot-candle) under different treatments during the two studied seasons of $2012-2013$.

\section{Vegetative growth parameters}

Concerning of vegetative growth, data in Tables 2 and 3 cleared that all protection treatments against the injury of high temperature used in this study led to a reduction in the period from transplanting to flowering date and at the same time produced tomato plants characterized by more vigorous in their vegetative growth expressed as plant height, number of branches and leaves per plants, fresh and dry weight and high in leaves chlorophyll content compared with those plants grown without protection treatments. The best treatments were happened with the plants shaded with black or green net followed by foliar sprayed treatment with purshade or robein. The superiority of the shading with black or green net may be due to the suitable environmental conditions (temperature, relative humidity and sun radiation) prevailing during growing period. However, the previous treatments led to a reduction in the temperature $\left(2-3{ }^{\circ} \mathrm{C}\right)$ around plants and sun radiation but increasing in relative humidity as mentioned before in Fig. 1, 2 \& 3. Since high temperature causes an increase in respiration, sometimes above the rate of photosynthesis which means that the products of photosynthesis are being used more rapidly than they are being produced. For growth to occur, photosynthesis must be greater than respiration. This result was in agreement with previous findings by Fosket (1994) and Chuartzman et al. (2008) they mentioned that reduce plant stresses improve the plants use of available resources. The changes in plants morphology induced by UV may affect competition for light (Barnes et al. 1988). Exposure to UV decrease plant height, leaf area and plant dry weight while increase auxiliary branching and leaf curling (Dai et al. 1995, Greenberg et al., 1997 and Furness et al. 1999). Dai et al. (1995) reported that after a few weeks of UV-B exposure, leaf area and plant dry weight of plants were significantly reduced. Similar results was found by

Egypt. J. Hort. Vol. 41, No.2 (2014) 
Abou-Hadid and El-Beltagy (1992) who stated that vegetative growth of the plants under protection were bigger than those plants grow under open field conditions.

TABLE 2. Effect of some treatments on number of days from transplanting to flowering, plant height, number of branches and number of leaves of tomato plants during 2012 and 2013 seasons under high temperature conditions.

\begin{tabular}{|c|c|c|c|c|c|c|c|c|}
\hline \multirow[t]{2}{*}{ Treatments } & \multicolumn{2}{|c|}{$\begin{array}{c}\text { No. of days } \\
\text { from } \\
\text { transplanting } \\
\text { to flowering }\end{array}$} & \multicolumn{2}{|c|}{$\begin{array}{l}\text { Plant height } \\
\text { (cm) }\end{array}$} & \multicolumn{2}{|c|}{$\begin{array}{c}\text { Number of } \\
\text { branches per } \\
\text { / plant }\end{array}$} & \multicolumn{2}{|c|}{$\begin{array}{c}\text { Number of } \\
\text { leaves per / } \\
\text { plant }\end{array}$} \\
\hline & 2012 & 2013 & 2012 & 2013 & 2012 & 2013 & 2012 & 2013 \\
\hline Black net & $29.3 \mathrm{c}$ & $27.3 \mathrm{c}$ & $81.6 \mathrm{a}$ & $85.0 \mathrm{a}$ & $5.3 \mathrm{a}$ & $6.0 \mathrm{ab}$ & $29.0 \mathrm{~b}$ & $30.0 \mathrm{a}$ \\
\hline Green net & $30.0 \mathrm{c}$ & $27.3 \mathrm{c}$ & $68.6 \mathrm{~b}$ & $71.6 \mathrm{~b}$ & $6.0 \mathrm{a}$ & $6.6 \mathrm{a}$ & $31.3 b$ & $39.3 \mathrm{a}$ \\
\hline +maize & $38.3 \mathrm{a}$ & $37.0 \mathrm{a}$ & $50.6 \mathrm{e}$ & $52.3 \mathrm{~d}$ & $3.7 b$ & $4.6 b c$ & $26.6 \mathrm{~b}$ & $30.0 \mathrm{a}$ \\
\hline +sunflower & $33.6 b$ & $32.0 \mathrm{~b}$ & $54.3 \mathrm{~d}$ & $55.0 \mathrm{~d}$ & $3.7 b$ & $4.3 \mathrm{c}$ & $28.1 \mathrm{~b}$ & $30.0 \mathrm{a}$ \\
\hline Purshade ${ }^{\circledR}$ pray & $33.3 b$ & $31.6 \mathrm{~b}$ & $63.0 \mathrm{c}$ & $64.6 \mathrm{c}$ & $5.0 \mathrm{ab}$ & $5.3 \mathrm{abc}$ & $40.0 \mathrm{a}$ & $44.6 \mathrm{a}$ \\
\hline Robein $^{(B)}$ spray & $32.6 b$ & $31.3 \mathrm{~b}$ & $63.3 \mathrm{c}$ & $64.6 \mathrm{c}$ & $5.5 \mathrm{ab}$ & $5.3 \mathrm{abc}$ & $39.0 \mathrm{a}$ & $40.0 \mathrm{a}$ \\
\hline Control & $38.3 \mathrm{a}$ & $35.3 a$ & $49.3 \mathrm{e}$ & $50.6 \mathrm{~d}$ & $3.7 \mathrm{~b}$ & $4.3 \mathrm{c}$ & $28.3 \mathrm{~b}$ & $31.0 \mathrm{a}$ \\
\hline
\end{tabular}

Duncan's multiple range test at $5 \%$.

The improved vegetative growth evidenced as plant height, number of branches, chlorophyll content, number of leaves, and stem diameter per plant under the protection against the unfavorable heat condition may be due to the favorable weather conditions, i.e., the increase in relative humidity, lower maximum temperature and light irradiance, higher minimum temperature and finally lower wind speed in comparison with open field conditions ( $\mathrm{Gu}$ et al., 2002 and Al-Helal \& Abdel-Ghany, 2010). Other possibility was increasing plant ability to uptake water and nutrients which ultimately accelerated the rate of vegetative growth under greenhouse conditions (Cerny et al., 2003). Moreover, the superiority of tomato plants grown under green net may be, due to the cover with net led to diffuse light and then increase radiation use efficiency, yields (both at the plant and ecosystem level), and even be a factor affecting plant growth (Ortiz and Cardemil, 2001). Any shade netting can scatter radiation, especially ultraviolet because netting is usually made using ultraviolet-resistant materials (Wong, 1994). Nissim-Levi et al. (2008) added that shade netting that increases light scattering but does not affect the light spectrum has been shown to increase branching, plant compactness, and total leaf area per plant (Shahak et al., 2004). The colored shade net can also increase light scattering by $50 \%$ or more and this alone may influence plant development and growth. On the other hand, black net reduce radiation reaching crops underneath (Shahak et al., 2004). Obviously, the higher 
the shade factor in dark net color, the more radiation will be blocked. Reductions in radiation resulting from netting will affect the climatic conditions under net and will reduce the plant growth especially in the winter season because of low natural radiation (Cerny et al., 2003 and Stamps, 2008).

TABLE 3. Effect of some treatments on fresh weight, dry weight and chlorophyll content (SPAD) unit of tomato plants during 2012 and 2013 seasons under high temperature conditions.

\begin{tabular}{|l|c|c|c|c|c|c|}
\hline \multirow{2}{*}{ Treatments } & \multicolumn{2}{|c|}{$\begin{array}{c}\text { Fresh weight } \\
\text { (g) }\end{array}$} & \multicolumn{2}{c|}{$\begin{array}{c}\text { Dry weight } \\
\text { (g) }\end{array}$} & \multicolumn{2}{c|}{$\begin{array}{c}\text { Chlorophyll } \\
\text { content (SPAD) } \\
\text { unit }\end{array}$} \\
\cline { 2 - 7 } & $\mathbf{2 0 1 2}$ & $\mathbf{2 0 1 3}$ & $\mathbf{2 0 1 2}$ & $\mathbf{2 0 1 3}$ & $\mathbf{2 0 1 2}$ & $\mathbf{2 0 1 3}$ \\
\hline Black net & $148.6 \mathrm{a}$ & $193.3 \mathrm{a}$ & $20.3 \mathrm{ab}$ & $27.7 \mathrm{a}$ & $33.9 \mathrm{c}$ & $35.3 \mathrm{~b}$ \\
\hline Green net & $168.6 \mathrm{a}$ & $197.6 \mathrm{a}$ & $25.3 \mathrm{a}$ & $29.7 \mathrm{a}$ & $49.7 \mathrm{a}$ & $51.4 \mathrm{a}$ \\
\hline +maize & $59.3 \mathrm{c}$ & $67.1 \mathrm{~b}$ & $9.0 \mathrm{c}$ & $10.9 \mathrm{~b}$ & $49.3 \mathrm{ab}$ & $50.7 \mathrm{a}$ \\
\hline + sunflower $^{*}$ & $56.6 \mathrm{c}$ & $63.3 \mathrm{~b}$ & $8.0 \mathrm{c}$ & $9.3 \mathrm{~b}$ & $44.3 \mathrm{a}$ & $44.9 \mathrm{ab}$ \\
\hline Purshade $^{\circledR}$ spray & $112.0 \mathrm{~b}$ & $120.5 \mathrm{ab}$ & $17.0 \mathrm{~b}$ & $19.5 \mathrm{ab}$ & $45.7 \mathrm{ab}$ & $47.7 \mathrm{ab}$ \\
\hline Robein $^{\circledR}$ spray & $108.3 \mathrm{~b}$ & $117.9 \mathrm{ab}$ & $16.0 \mathrm{~b}$ & $18.3 \mathrm{ab}$ & $50.0 \mathrm{a}$ & $51.6 \mathrm{a}$ \\
\hline Control $^{*}$ & $62.6 \mathrm{c}$ & $77.7 \mathrm{~b}$ & $9.3 \mathrm{c}$ & $11.9 \mathrm{~b}$ & $41.4 \mathrm{~b}$ & $42.8 \mathrm{ab}$ \\
\hline
\end{tabular}

Values having an alphabetical letter in common within column do not statistically differ, using Duncan's multiple range test at $5 \%$.

Number of clusters, fruit set (\%), early, total yield (ton/fed.) and average tomato fruit weight $(g)$

Data in Table 4 showed that all treatments were significantly have positive effect on the parameters of number of clusters/plant, fruit set $\%$, early and total yields and fruit weight of tomato plants which protected against high temperature by black or green net compared with the control especially when the plants shaded with the green color net. These results might be attributed to the favorable effect of temperature during the period of growth and reproduction process which possessed much shoot and leaves number per plant and width leaf area with high leaf chlorophyll content as mentioned before that induce more photosynthetic rates. On the contrary, the lowest previous parameters were obtained with those plants grown without protection (control) because of the exposing to high temperature .However, poor fruit set at high temperature has also been associated with low levels of carbohydrates and growth regulators released in plants tissues (Safia et al., 2002). Also under high temperatures, fruit set in tomato plants failed due to the disruption of sugar metabolism (Sato et al., 2006 and Medany et al., 2009). The increasing in tomato total yield under green net maybe due to the plants don't suffer from the heat stress under the net, the plants has good vegetative growth, better pollination and finally higher yield (Safia et al., 2002).

Egypt. J. Hort. Vol. 41, No.2 (2014) 
TABLE 4. Effect of some treatments on clusters number, fruit setting \%, early, total yield and average fruit weight of tomato plants during 2012 and 2013 seasons under high temperature conditions.

\begin{tabular}{|l|c|c|c|c|c|c|c|c|c|c|}
\hline \multirow{2}{*}{ Treatments } & \multicolumn{2}{|c|}{$\begin{array}{c}\text { Number of } \\
\text { clusters/plant }\end{array}$} & \multicolumn{2}{|c|}{$\begin{array}{c}\text { Fruit setting } \\
\%\end{array}$} & \multicolumn{2}{c|}{$\begin{array}{c}\text { Early yield } \\
\text { (tons/fed) }\end{array}$} & \multicolumn{2}{|c|}{$\begin{array}{c}\text { Total yield } \\
\text { (tons/fed) }\end{array}$} & \multicolumn{2}{|c|}{$\begin{array}{c}\text { Average fruit } \\
\text { weight }(\mathbf{g})\end{array}$} \\
\cline { 2 - 12 } & $\mathbf{2 0 1 2}$ & $\mathbf{2 0 1 3}$ & $\mathbf{2 0 1 2}$ & $\mathbf{2 0 1 3}$ & $\mathbf{2 0 1 2}$ & $\mathbf{2 0 1 3}$ & $\mathbf{2 0 1 2}$ & $\mathbf{2 0 1 3}$ & $\mathbf{2 0 1 2}$ & $\mathbf{2 0 1 3}$ \\
\hline Black net & $9.0 \mathrm{bc}$ & $9.6 \mathrm{ab}$ & $68.3 \mathrm{ab}$ & $70.0 \mathrm{ab}$ & $7.6 \mathrm{~b}$ & $8.2 \mathrm{~b}$ & $26.6 \mathrm{~b}$ & $27.4 \mathrm{~b}$ & $105.6 \mathrm{~b}$ & $106.6 \mathrm{~b}$ \\
\hline Green net & $11.3 \mathrm{a}$ & $14.0 \mathrm{a}$ & $77.6 \mathrm{a}$ & $78.3 \mathrm{a}$ & $8.7 \mathrm{a}$ & $9.6 \mathrm{a}$ & $30.8 \mathrm{a}$ & $31.8 \mathrm{a}$ & $140.6 \mathrm{a}$ & $146.6 \mathrm{a}$ \\
\hline +maize & $8.0 \mathrm{~cd}$ & $9.3 \mathrm{ab}$ & $45.0 \mathrm{c}$ & $45.0 \mathrm{~d}$ & $3.0 \mathrm{~h}$ & $3.3 \mathrm{f}$ & $17.9 \mathrm{f}$ & $18.6 \mathrm{~g}$ & $67.7 \mathrm{e}$ & $68.3 \mathrm{c}$ \\
\hline +sunflower & $7.3 \mathrm{~cd}$ & $7.3 \mathrm{~b}$ & $45.3 \mathrm{c}$ & $46.6 \mathrm{~d}$ & $3.8 \mathrm{e}$ & $4.2 \mathrm{e}$ & $19.1 \mathrm{e}$ & $19.9 \mathrm{f}$ & $73.0 \mathrm{cde}$ & $73.3 \mathrm{c}$ \\
\hline $\begin{array}{l}\text { Purshade } \\
\text { spray }\end{array}$ & $11.3 \mathrm{a}$ & $12.0 \mathrm{ab}$ & $61.0 \mathrm{~b}$ & $62.3 \mathrm{bc}$ & $5.5 \mathrm{~d}$ & $5.9 \mathrm{~d}$ & $22.1 \mathrm{~d}$ & $23.2 \mathrm{~d}$ & $75.6 \mathrm{~cd}$ & $81.6 \mathrm{c}$ \\
\hline $\begin{array}{l}\text { Robein } \\
\text { spray }\end{array}$ & $10.0 \mathrm{ab}$ & $10.3 \mathrm{ab}$ & $72.6 \mathrm{a}$ & $75.0 \mathrm{ab}$ & $6.0 \mathrm{c}$ & $6.6 \mathrm{c}$ & $23.5 \mathrm{c}$ & $24.6 \mathrm{c}$ & $69.0 \mathrm{de}$ & $70.0 \mathrm{c}$ \\
\hline Control $^{\circledR}$ & $7.0 \mathrm{~d}$ & $8.0 \mathrm{~b}$ & $51.0 \mathrm{c}$ & $53.3 \mathrm{~cd}$ & $3.5 \mathrm{e}$ & $4.3 \mathrm{e}$ & $19.9 \mathrm{e}$ & $21.0 \mathrm{e}$ & $77.6 \mathrm{c}$ & $83.3 \mathrm{c}$ \\
\hline
\end{tabular}

Values having an alphabetical letter in common within column do not statistically differ, using Duncan's multiple range test at $5 \%$.

\section{Fruit quality}

\section{Physical characteristics of tomato fruits}

Data in Table 5 showed that all protection treatments under investigation enhanced the fruit physical characters i.e. fruit length, fruit diameter, umber of locules and flesh thickness. Especially with the use of the green net in comparison with other protected cultivation treatments as well as control. These results might be attributed to the protection treatments which favor plant growth, since plants are less stressful, direct sunlight was avoided, temperature is lower, humidity is higher, wind speed reduced, and ETc. was low. In addition, water use efficiency increased under shady conditions (Jifon and Syvertsen, 2003). These results also might be attributed to the favorable effect of temperature during the period of growth and reproduction process which reduced crop transpiration and thus water uptake, and improved water use and moisture availability in the soil which might have increased various physiological processes, better plant nutrient uptake, higher rates of photosynthesis, which might reflect on more number of fruits and higher fruit weight (Ngouajio et al., 2007). Furthermore, the reduction of radiation is responsible for down-regulation of photosynthetic capacity of leaves and consequently a lower light saturated photosynthetic rate compared to the control (Abdrabbo et al. 2009). 
TABLE 5. Effect of some treatments on physical characters of tomato fruits during 2012 and 2013 seasons under high temperature conditions.

\begin{tabular}{|l|c|c|c|c|c|c|c|c|c|c|}
\hline \multirow{2}{*}{ Treatments } & \multicolumn{2}{|c|}{$\begin{array}{c}\text { Fruit length } \\
(\mathbf{c m})\end{array}$} & \multicolumn{2}{|c|}{$\begin{array}{c}\text { Fruit diameter } \\
(\mathbf{c m})\end{array}$} & \multicolumn{2}{c|}{$\begin{array}{c}\text { Fruit } \\
\text { firmness } \\
\left(\mathbf{k g} / \mathbf{c m}^{2}\right)\end{array}$} & \multicolumn{2}{c|}{$\begin{array}{c}\text { Number of } \\
\text { locules }\end{array}$} & \multicolumn{2}{|c|}{$\begin{array}{c}\text { Flesh } \\
\text { thickness } \\
(\mathbf{c m})\end{array}$} \\
\cline { 2 - 11 } & $\mathbf{2 0 1 2}$ & $\mathbf{2 0 1 3}$ & $\mathbf{2 0 1 2}$ & $\mathbf{2 0 1 3}$ & $\mathbf{2 0 1 2}$ & $\mathbf{2 0 1 3}$ & $\mathbf{2 0 1 2}$ & $\mathbf{2 0 1 3}$ & $\mathbf{2 0 1 2}$ & $\mathbf{2 0 1 3}$ \\
\hline Black net & $5.7 \mathrm{ab}$ & $5.8 \mathrm{~b}$ & $4.9 \mathrm{~b}$ & $5.3 \mathrm{~b}$ & $2.6 \mathrm{~d}$ & $2.9 \mathrm{c}$ & $3.3 \mathrm{a}$ & $3.7 \mathrm{ab}$ & $0.57 \mathrm{a}$ & $0.63 \mathrm{ab}$ \\
\hline Green net & $6.1 \mathrm{a}$ & $6.6 \mathrm{a}$ & $5.6 \mathrm{a}$ & $6.1 \mathrm{a}$ & $3.0 \mathrm{bc}$ & $3.9 \mathrm{~b}$ & $3.3 \mathrm{a}$ & $4.2 \mathrm{a}$ & $0.56 \mathrm{a}$ & $0.70 \mathrm{a}$ \\
\hline +maize & $4.5 \mathrm{~d}$ & $4.9 \mathrm{e}$ & $4.1 \mathrm{~d}$ & $4.6 \mathrm{e}$ & $3.0 \mathrm{bc}$ & $3.2 \mathrm{~b}$ & $3.3 \mathrm{a}$ & $3.8 \mathrm{~b}$ & $0.38 \mathrm{~b}$ & $0.44 \mathrm{~d}$ \\
\hline +sunflower & $4.9 \mathrm{~cd}$ & $5.3 \mathrm{~cd}$ & $4.5 \mathrm{bcd}$ & $4.7 \mathrm{de}$ & $2.5 \mathrm{~d}$ & $2.7 \mathrm{c}$ & $3.6 \mathrm{a}$ & $3.9 \mathrm{ab}$ & $0.40 \mathrm{~b}$ & $0.52 \mathrm{~cd}$ \\
\hline $\begin{array}{l}\text { Purshade } \\
\text { spray }\end{array}$ & $4.9 \mathrm{~cd}$ & $5.4 \mathrm{bcd}$ & $4.6 \mathrm{bcd}$ & $4.9 \mathrm{~cd}$ & $3.1 \mathrm{~b}$ & $3.4 \mathrm{ab}$ & $3.7 \mathrm{a}$ & $3.9 \mathrm{ab}$ & $0.47 \mathrm{ab}$ & $0.49 \mathrm{~cd}$ \\
\hline $\begin{array}{l}\text { Robein } \\
\text { spray }\end{array}$ & $4.43 \mathrm{~d}$ & $5.1 \mathrm{de}$ & $4.3 \mathrm{~cd}$ & $4.6 \mathrm{e}$ & $2.8 \mathrm{~cd}$ & $2.9 \mathrm{c}$ & $3.3 \mathrm{a}$ & $3.7 \mathrm{ab}$ & $0.43 \mathrm{ab}$ & $0.51 \mathrm{~cd}$ \\
\hline Control & $5.3 \mathrm{bc}$ & $5.6 \mathrm{bc}$ & $4.8 \mathrm{bc}$ & $5.1 \mathrm{bc}$ & $3.4 \mathrm{a}$ & $3.5 \mathrm{a}$ & $3.3 \mathrm{a}$ & $3.3 \mathrm{~b}$ & $0.46 \mathrm{ab}$ & $0.56 \mathrm{bc}$ \\
\hline
\end{tabular}

Values having an alphabetical letter in common within column do not statistically differ, using Duncan's multiple range test at $5 \%$

\section{Chemical characters of tomato fruits}

Regarding to the fruit chemical quality the data in Table 6 showed that there were no significant differences between the studied treatments on the fruit color characters and acidity of fruit juice during the two studied seasons. Regarding fruit TSS it is decreased under the shade comparing with the other protected cultivation methods. The highest fruit TSS was obtained from shading by maize plants followed by Robin algae and Purshade treatments, the lowest TSS was obtained by shading by green net treatment. The obtained results agreed with those of Kinet and Peet (1997), Safia et al. (2002), Foolad (2005) and Sato et al. (2006).

TABLE 6. Effect of some treatments on chemical characters of tomato fruits (color, TSS and acidity) during 2012 and 2013 seasons under high temperature conditions.

\begin{tabular}{|l|c|c|c|c|c|c|c|c|c|c|}
\hline \multirow{3}{*}{ Treatments } & \multicolumn{6}{|c|}{ Color characters } & \multicolumn{3}{|c|}{ TSS } & \multicolumn{2}{|c|}{ Juice acidity } \\
\cline { 2 - 11 } & L (lightness) & C (Chroma) & \multicolumn{1}{|c|}{ H (hug angle) } & \multicolumn{2}{|c|}{} & & \\
\cline { 2 - 11 } & $\mathbf{2 0 1 2}$ & $\mathbf{2 0 1 3}$ & $\mathbf{2 0 1 2}$ & $\mathbf{2 0 1 3}$ & $\mathbf{2 0 1 2}$ & $\mathbf{2 0 1 3}$ & $\mathbf{2 0 1 2}$ & $\mathbf{2 0 1 3}$ & $\mathbf{2 0 1 2}$ & $\mathbf{2 0 1 3}$ \\
\hline Black net & $45.1 \mathrm{a}$ & $46.1 \mathrm{a}$ & $47.4 \mathrm{a}$ & $47.9 \mathrm{a}$ & $52.6 \mathrm{a}$ & $54.1 \mathrm{a}$ & $4.6 \mathrm{ab}$ & $4.99 \mathrm{~b}$ & $3.97 \mathrm{a}$ & $3.97 \mathrm{a}$ \\
\hline Green net & $45.7 \mathrm{a}$ & $47.1 \mathrm{a}$ & $48.6 \mathrm{a}$ & $49.0 \mathrm{a}$ & $52.2 \mathrm{a}$ & $52.8 \mathrm{a}$ & $3.8 \mathrm{c}$ & $4.84 \mathrm{~b}$ & $4.08 \mathrm{a}$ & $4.09 \mathrm{a}$ \\
\hline +maize & $46.8 \mathrm{a}$ & $47.6 \mathrm{a}$ & $49.6 \mathrm{a}$ & $51.1 \mathrm{a}$ & $54.4 \mathrm{a}$ & $55.4 \mathrm{a}$ & $5.1 \mathrm{a}$ & $5.80 \mathrm{a}$ & $4.06 \mathrm{a}$ & $4.07 \mathrm{a}$ \\
\hline +sunflower & $47.6 \mathrm{a}$ & $49.2 \mathrm{a}$ & $51.6 \mathrm{a}$ & $52.8 \mathrm{a}$ & $56.6 \mathrm{a}$ & $58.3 \mathrm{a}$ & $4.3 \mathrm{bc}$ & $4.83 \mathrm{~b}$ & $4.08 \mathrm{a}$ & $4.09 \mathrm{a}$ \\
\hline $\begin{array}{l}\text { Purshade } \\
\text { spray }\end{array}$ & $45.7 \mathrm{a}$ & $47.0 \mathrm{a}$ & $46.5 \mathrm{a}$ & $48.3 \mathrm{a}$ & $53.1 \mathrm{a}$ & $55.9 \mathrm{a}$ & $4.8 \mathrm{ab}$ & $5.23 \mathrm{~b}$ & $4.11 \mathrm{a}$ & $4.11 \mathrm{a}$ \\
\hline $\begin{array}{l}\text { Robein } \\
\text { spray }\end{array}$ & $48.7 \mathrm{a}$ & $50.1 \mathrm{a}$ & $51.1 \mathrm{a}$ & $52.1 \mathrm{a}$ & $53.6 \mathrm{a}$ & $57.2 \mathrm{a}$ & $4.9 \mathrm{ab}$ & $5.33 \mathrm{ab}$ & $4.07 \mathrm{a}$ & $4.19 \mathrm{a}$ \\
\hline Control & $45.2 \mathrm{a}$ & $46.7 \mathrm{a}$ & $46.1 \mathrm{a}$ & $47.5 \mathrm{a}$ & $54.5 \mathrm{a}$ & $55.7 \mathrm{a}$ & $4.3 \mathrm{bc}$ & $4.87 \mathrm{~b}$ & $4.01 \mathrm{a}$ & $4.02 \mathrm{a}$ \\
\hline
\end{tabular}

Values having an alphabetical letter in common within column do not statistically differ, using Duncan's multiple range test at $5 \%$.

Egypt. J. Hort. Vol. 41, No.2 (2014) 


\section{Conclusion}

Using of black and green net for Reduce the harmful effect of high temperature was most effective than using the other treatments (Spray of Purshade or sea algae and intercropping tomato with sunflower or maize). The black and green net treatments enhanced tomato production as it increased total and marketable yields, beside the increase of yield components, when compared with other treatments. This study recommends the use green or black net to protect tomato plants which cultivated during summer season to improve the productivity under conditions especially of newly reclaimed land.

\section{References}

Abdel-Aziz, M.A. and Zakher, A.G. (2010) Effect of foliar spray with some compounds for improving yield and quality of pea pods (Pisum sativum L.) Egypt J. Appl. Sci., 25 (9), 35-43.

Abdrabbo, M.A.A., Farag, A.A. and Hassanein, M.K. (2009) Irrigation requirements for cucumber under different mulch colors. Egypt. J. Hort., 36, 333-346.

Abdrabbo, M.A., Farag, A.A. and Abul-Soud, M. (2013) Intercropping effect on potato under net house as adaption procedure of climate change impacts. Researcher, 5, 4860 .

Abou-Hadid, A.F. and El-Beltagy, A.S. (1992) Pan evaporation under plastic houses as a function of open field climate. Acta Hort., 323, 33-36.

Adams, S.R., Valdes, V.M., Cave, C.R.J. and Fenlon, J.S. (2001) The impact of changing light levels and fruit load on the pattern of tomato yields. J. Hort. Sci., 76, 368-374.

Al-Helal, I.M. and Abdel-Ghany, A.M. (2010) Responses of plastic shading nets to global and diffuse PAR transfer: Optical properties and evaluation. Wageningen J. Life Sci., 57, 125-132.

Association of Official Agricultural Chemists (A.O.A.C.) (1990) "Methods of Analysis", $15^{\text {th }}$ ed. Washington D.C., USA.

Barnes, P.W., Jordan, P.W., Flint, W.G. and Caldwell, M. (1988) Competition, morphology and canopy structure in wheat (Triticum aestivum L.) and wild oat (Avena fatua L.) exposed to enhanced ultraviolet-B radiation. Funct. Ecol., 2, 391-330.

Campen, J.B. and Bot, G.P.A. (2003) Determination of greenhouse-specific aspects of ventilation using three-dimensional computational fluid dynamics. Biosystem Engineering, 84 (1), 69-77.

Cerny, T.A., Faust, J.E. Layne, D.R. and Rajapakse, N.C. (2003) Influence of photoselective films and growing season on stem growth and flowering of six plant species. J. Amer. Soc. Hort. Sci., 128, 486-491. 
Chuartzman, S.G., Nevo, R., Shimoni, E., Charuvi, D., Kiss, V., Ohad, I., Brumfeld, V. and Reich, Z. (2008) Thylakoid membrane remodeling during state transitions in Arabidopsis. Plant Cell, 20, 1029-1039.

Dai Q., Peng, S., Chavez, A.Q. and Vergara, B.S. (1995) Effects of UV-B radiation on stomatal density and opening in rice (Oryza sativa L.) Ann. Bot., 76, 65-70.

Dubey, R.S. (1997) Photosynthesis in plants under stressful conditions, In: Handbook of Photosynthesis, Pessarakli, M. (Ed.), pp. 859-875, Marcel Dekker Inc, New York.

Elad, Y., Messika, Y., Brand, M., David, D.R. and Sztejnberg, A. (2007) Effect of colored shade nets on pepper powdery mildew (Leveillula taurica). Phytoparasitica 35, 285- 299 .

Foolad, M.R. (2005) Breeding for abiotic stress tolerances in tomato. In: Abiotic Stresses: Plant Resistance Through Breeding and Molecular Approaches. Ashraf, M., Harris, P.J.C. (Ed.), pp. 613-684, The Haworth Press Inc., New York, USA,

Fosket, D.E. (1994) Plant Growth and Development: A Molecular Approach, Academic Press, New York, p. 580.

Furness, N., Upadhyaya, M.K. and Ormrod, D.P. (1999) Seedling growth and leaf surface morphological responses of three rangeland weeds to ultraviolet-B radiation. Weed Sci., 47, 427-434.

Greenberg, B.M., Wilson, M.I., Huang, X.D., Duxbury, C.L., Gerhaddt, K.E. and Gensemer, R.W. (1997) The effects of ultraviolet-B radiation on higher plants. In: Plants for environmental studies, Wang, W., Goursuch, J., Hughes, J.S. (Ed.), Boca Raton, Fl: CRC Press, pp.1-35.

Gu, L.H., Baldocchi, D., Verma, S.B., Black, T.A., Vesala, T., Falge, E.M. and Dowty, P.R. (2002) Advantages of diffuse radiation for terrestrial ecosystem productivity. $J$. Geophys. Res., 107(D6), ACL 2-1-23.

Iglesias, I. and Alegre, S. (2006) The effect of anti-hail nets on fruit protection, radiation, temperature, quality and profi tability of 'Mondial Gala' apples. Journal of Applied Horticulture, 8 (2), 91-100.

IPCC (2006) IPCC Guidelines for National Greenhouse Gas Inventories, Vol. 4, Prepared by the National Greenhouse Gas Inventories Programme, edited by: Eggleston, H. S., Buendia, 20p.

Jensen, E. (2004) Seaweed, fact or fancy. Published by Moses the Midwest Organic and Sustainable Education. From the broad Caster. 12 (3), 164170.

Jifon, J.L., and Syvertsen, J.P. (2003) Kaolin particle film applications can increase photosynthesis and water use efficiency of 'Ruby red'grapefruit leaves. J. Amer. Soc. Hort. Sci., 128, 107-112.

Jones, P.D., New, M., Parker, D.E., Mortin, S. and Rigor, I.G. (1999) Surface area temperature and its change over the past 150 years, Rev. Geophys., 37, 173-199.

Egypt. J. Hort. Vol. 41, No.2 (2014) 
Karim, M.A., Fracheboud, Y. and Stamp, P. (1999) Photosynthetic activity of developing leaves of Zea mays is less affected by heat stress than that of developed leaves, Physiol. Plant, 105, 685-693.

Kowalski, B., Jager, A.K. and Vanstaden, J. (1999) The effect of seaweed concentrate on the invitro growth and acclimatization of the potato plants. Potato Research, 42(1), 131-139.

Kinet, J.M. and Peet, M.M. (1997) Tomato. In: The Physiology of Vegetable Crops. Wien, H. C. (Ed.), CAB International, Wallingford, UK, pp. 207-258.

McGuire, R.G. (1992) Reporting of objective color measurements. HortScience, 27, 1254-1255.

Medany, M.A., Abdrabbo, M.A.A., Awny, A.A., Hassanien, M.K. and Abou-Hadid, A.F. (2009) Growth and productivity of mango grown under greenhouse conditions. Egypt. J. Hort., 36, 373-382.

Monje, O.A. and Bugbee, B. (1992) Inherent limitations of nondestructive chlorophyll meters: a comparison of two types of meters. Hortscience, 27, 69-71.

Ngouajio, M., Wang, G. and Goldy, R. (2007) Withholding of drip irrigation between transplanting and flowering increases the yield of field-grown tomato under plastic mulch. Agric. Water Manage, 87, 285-291.

Nissim-Levi, A., Farkash, L., Hamburger, D., Ovadia, R., Forrer, I., Kagan, S. and Oren-Shamir, M. (2008) Light-scattering shade net increases branching and flowering in ornamental pot plants. J. Hort. Sci. Biotechnol., 83, 9-14

Ortiz, C. and Cardemil, L. (2001) Heat-shock responses in two leguminous plants: a comparative study. J. Exp. Bot., 52, 1711-1719.

Rajapakse, N.C. and Shahak, Y. (2007) Light quality manipulation by horticulture industry. Light and Plant Development, In: Whitelam, G. and Halliday, K. (Ed.), Blackwell Publishing, UK, pp 290-312.

Retamales, J.B., Montecino, J.M., Lobos, G.A. and Rojas, L.A. (2008) Colored shading nets increase yields and profitability of highbush blueberries. Acta Hort., 770, 193-197.

Safia M., Adam, A. Abdalla, M. and Abou-Hadid, A.F. (2002) Effect of shading on the growth and productivity of some tomato cultivars in the Summer season, Egypt. J. Hort., 29, 271-280.

Sato, S., Kamiyama, M., Iwata, T., Makita, N., Furukawa, H. and Ikeda, H. (2006) Moderate increase of mean daily temperature adversely affects fruit set of Lycopersicon esculentum by disrupting specific physiological processes in male reproductive development. Ann. Bot., 97, 731-738.

Shahak, Y., Gussakovsky, E.E., Gal, E. and Ganelevin, R. (2004) Colour Nets: Crop protection and light-quality manipulation in one technology. Acta Horticulturae, 659 , $143-151$. 
Stamps, R.H. (2008) Differential effects of colored shade nets on three cut foliage crops. Acta Hort., 770, 169-176. Vaysse, P. (1997) Incidences climatique, phytosanitarie et agronomique des filets. Infos-Ctifl., 128, 6 .

Waller, R.A. and Duncan, D.B. (1969) Ways for the symmetric multiple comparison problem. Amer. Stat. Assoc. J., 19, 1485-1503

Wilson, S.B. and Rajapakse, N.C. (2001) Growth regulation of sub-tropical perennials by photoselective plastic films. J. Environ. Hort., 19, 65- 68 .

Wong, C.F. (1994) Scattered ultraviolet radiation underneath a shade-cloth. Photodermatol. Photoimmunol. Photomed., 10, 221-224.

(Received 15/ 5/2014; accepted 1/9/2014) 


\section{تقليل الأثر الضار للحرارة المرتفعة لتحسين انتاجية الطماطم تحت ظروف الاراضي المستصلحة حديثاً}

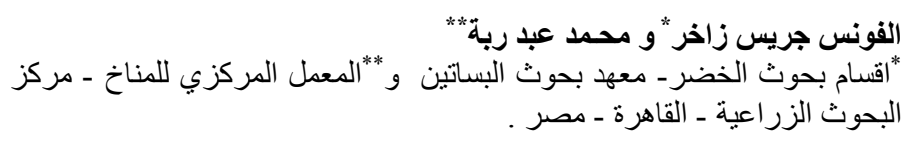

يتأثر نمو وإنتاجية الطماطم هجين اليسا من خلال العوامل البيئية والتقنيات

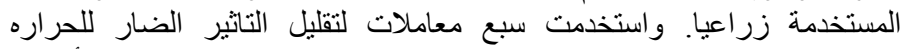

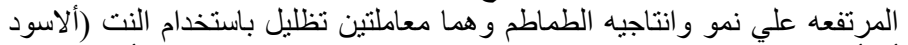

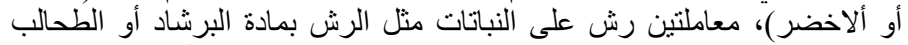

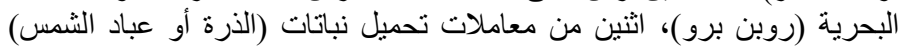

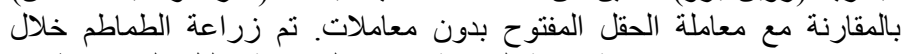

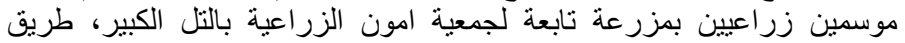

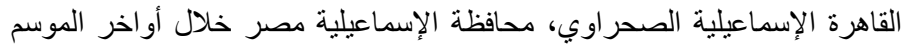

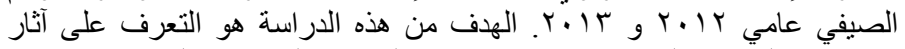

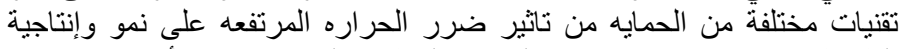

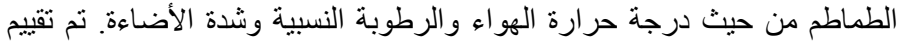

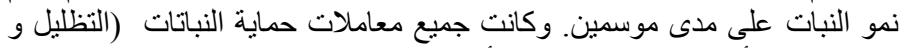

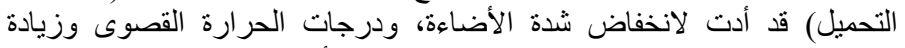

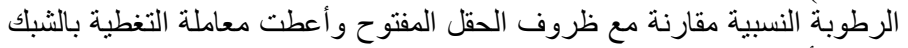

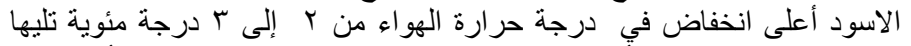

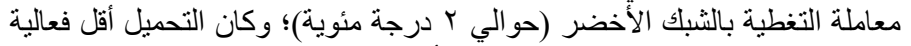

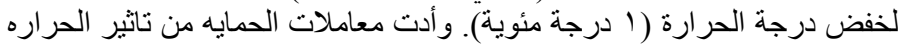

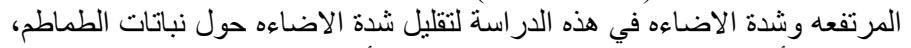

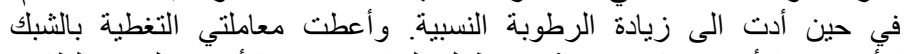

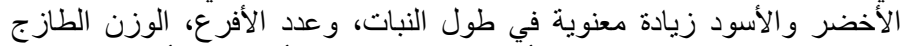

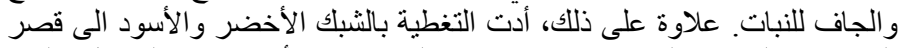

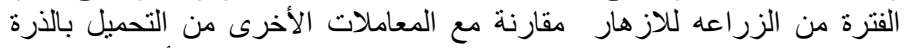

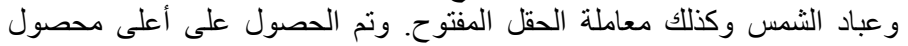

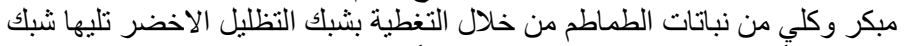

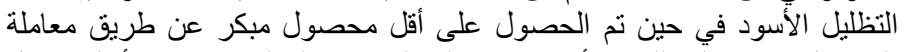

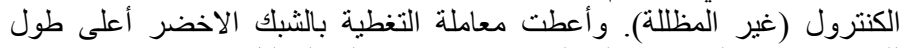

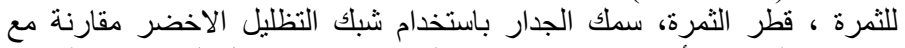

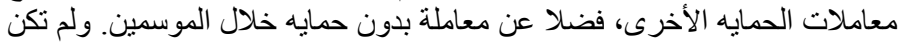
هناك فروق معنوية بين المعاملات فيما يخص لون الثمن الثمرة ودرجة الحموضة خلال

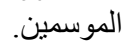

الكلمات الرئيسية: شبك التظليل الملون، الإثعاع الثمسي، شدة الضوء، الرطوبة

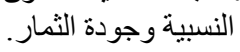

